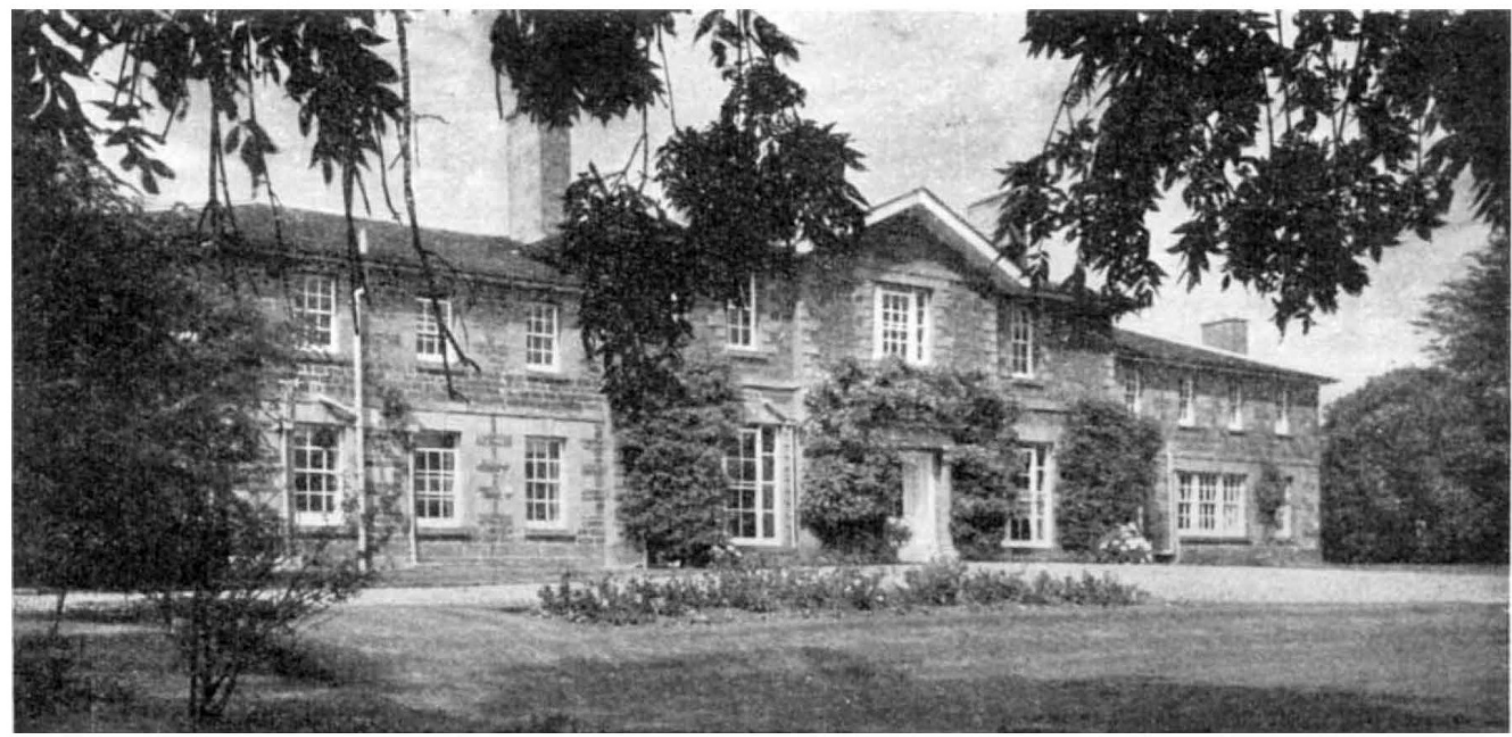

Fig. 2. Caswell House at the Allen Clark Research Centre of The Plessey Company, where research and development started in 1940

metals and oxides. Further, there is a section which deals with the anodization of various metals, studying the mechanism of oxide growth and correlating the results with the electrical properties. Examples of components developed in this Group are ceramic capacitors, many forms of ferrites, computer storage devices, thin-film resistor and capacitor component notworks and electrolytic capacitors.

A High Temperature Materials Group works in the field of materials associated with applications in the aircraft, nuclear and high-temperature component fields. Examples of the work include metal ceramic seals, high-purity donse alumina and cermets, the latter being mixtures of metals and metal oxides.

A Radar Materials Group is concerned primarily with research and development of materials for microwave applications, microwave absorbers being the principal interest. Examples of the applications are the building of dark-rooms in which microwave measurements can be carried out without interference from undesirable echoes from the surrounding walls. Another is the improvement of precision radar approach systems on airfields where false echoes thrown up on the observer's radar screen by the structure supporting the light housings seriously interfere with the clarity of the picture. By coating the light housing supports, the radar sereen gives a clear picture of the landing. Similar applications occur at sea where false echoes from the superstructure of ships produce false images on the radar screen and can confuse the observer's interpretation of the picture.

Finally, there are two groups which are closely allied. They work in the fields of Solid State Chemistry and Solid State Physics. They are concerned with a wide range of materials leading to the development of all forms of semiconductor devices working in the field of super-pure materials, single-crystal thin films by epitaxial growth and low-temperature physics. Examples of the applications include various forms of transistors and diodes, solid circuits, thermoelectric generators, electroluminescent devices and lasers.

The Development Division is equipped to take over ideas from the Research Section, and, with the aid of a small pilot plant unit, to prepare the way to full-scale produc. tion. This unit is primarily concerned with semiconductor device development, and items of major interest at present are solid circuits and solar cells.

In a laboratory such as the Allen Clark Research Centre it is essential to have a good central technical service for the chemical and physical investigations of the products. In this respect there are many facilities, such as radio-chemistry, $\mathrm{X}$-ray crystallography, electron microscopy, spectroscopy, etc. Scientific information and advice are provided by maintaining close contact with the universities through a consultant staff of lecturers and professors and an effective central library system.

\title{
OBITUARIES
}

\section{Sir David Brunt, K.B.E., F.R.S.}

Sir David Brunt, a member of the Meteorological Office from 1916 until 1934, professor of meteorology at the Imperial College of Science and Technology from 1934 until 1952, and physical secretary of the Royal Society from 1948 until 1957, died on February 5 at the age of seventy-eight.

Brunt was born into a large family in the hamlet of Staylittle, Montgomeryshire, where he attended the local Board School until the age of ten. The family then moved to Monmouthshire and Brunt attended the Intermediate School, Abertillery, which he left at eighteen for University College, Aberystwyth, where he took a 'first' in mathematics. He proceeded to Cambridge but with the love of his soil, particularly of Central Wales, strong within him, and he would return to walk its countryside whenever opportunity later offered. A 'first' in the mathematical Tripos led to the Isaac Newton studentship (1911-13) and, under the stimulus of F. J. M. Stratton, to work in astronomy. He ran into problems of observational analysis which, joined with a liking for the manipulation of numbers, led Brunt to prepare his well-known book The Combination of Observations. It appeared first in 1917 and continued, through several editions, to meet a demand until well after the Second World War.

From 1913 until 1915 Brunt lectured in mathematics, first at the University of Birmingham, and then at Monmouth Teachers' Training College. He entered the Meteorological Office in the early days of 1916 and after a 
few months of preparation proceeded to Franco to provide moteorological advico to the Army and the Royal Flying Corps. On domobilization he was appointed superintondent of Army Services in the Meteorological Office, and by virtuo of that position or of the time it left available for other activities Brunt was quickly able to influence the development of meteorology in Britain. Thus, he was responsible for a famous research group on atmospheric diffusion at the Chemical Defence Establishment, Porton, Wiltshire, and in a day when (Government science was not much given to basic resoarch encouraged that group to take the broadest view of its scientific responsibilities. The dividend was unquestionable. Again, Sir Napier Shaw had rotired from the directorship of the Metoorological Office in 1920 to become the first holder of a part-time professorship of meteorology at the Imperial College of Science and Technology, and he quickly enlisted Brunt's assistance as a visiting lecturer for a course in physical meteorology. That course, given at a time when no adoquate toxt existed, laid the foundations of Brunt's Physical and Dynamical Meteorology, which was to appear a. decade later.

The chair at Imperial Collego became a full-time appointment in 1934 and Brunt was its first holder, the Departmont being essentially postgraduate. He had no other staff until 1939 when ho was joined by a reader, but the Second World War came and the Department went into 'cold storago'. Then, in the post-war period, tho Department grew and blossomod so that whon, in 1952, Brunt retired ho left behind him one of tho most notable and active schools of meteorology in the world.

Brunt's own research in metcorology coverod a broad front. It began offoctively in 1919 with the question of long-term poriodicity in weather about which extravagant claims had been-and somotimes still are-mado. His poriodogram analysis of the long Greenwich temperature record and, later, of central European rocords, showed that these records had in themselves no predictive value. Work on various dynamical problems followed, particularly on the rate of dissipation of the kinetic energy of the winds and, with C. K. M. Douglas, on weather-producing air motions associated with the field of baromotric tendencyso-called isallobaric winds. Atmospheric (water vapour) radiation, its intensity and role as an agent of heat transfer in the atmosphere, was a later interost, and Brunt finally directod his attention to the reaction of the human body to its environment. Nearly all his work carried a very personal stamp-of the isolation of a moderately selfcontained problem, commonly presented by a body of observations, of its illumination by simplo but incisive physical insight and its transformation by suitably chosen but generally quito unsophisticated mathematics. Boyond all his research, however, Brunt's outstanding contribution to meteorology was his classical text Physical and Dynamical Meteorology (1934, second edition 1939). In it a coherent field of study began to emerge, and though the subject has now outgrown the toxt at many points it remains the most valuablo single volume for to-day's scrious student.

Brunt wiss a devoted servant of physical science in Britain. Ho was president of tho Royal Meteorological Society from 1942 until 1944, having earlier edited its Quarterly Journal; he was president of the Physical Society from 1945 until 1947 , and then followed his nine yoars of unsparing service to tho Royal Society as physical secretary. In that capacity he supervised Britain's contribution to tho International Geophysical Year and, particularly, the Royal Society expedition to Halley Bay in Antarctica -an ice sholf is now named in his honour there. He also encouraged the development of electronic computers in Britain and saw to it that they were mado available to university scientists.

Many honours came to Brunt. Ho was knighted in 1949 and created K.B.F. in 1959. The Royal Metcorological Society awarded him its Buchan Prize in 1937 and its
Symons Gold Medal in 1947. He received a Royal Medal in 1944.

Brunt's zest for life was outstanding, and tho many who enjoyed his companionship could not fail to be infected by his enthusiasm. Utterly loyal to his friends and colleagues, he hated tho pompous or sham and was short with it. His attitude to life, as to science, was empirical, and ho distrusted theory until it had been through the fire of experience. This was his strongth.

\section{P. A. Sheppard}

\section{Prof. Thomas Wallace, C.B.E., F.R.S.}

Emeritus l'rofmssor Thomas Wallace, before his retiroment professor of horticultural chomistry in tho University of Bristol and director of the Long Ashton Research Station, was one of the outstanding agricultural sciontists of his time. Graduating just before the First World War, he served with distinction in Flanders and Gallipoli, where ho won the Military Cross and was severcly wounded, an injury which loft him with a permanently stiff knee. Characteristically ho never complained of a handicap which must have made his later work in the field difficult.

On his release from military service in 1919, he was appointed as research chemist to the Long Ashton Research Station. In 1923 he became deputy diroctor and in 1943 director of the Institute, a post ho held until his retirement in 1959 . Soon after his appointment to Long Ashton, Wallace began his classical studies on plant nutrition. From the beginning his work had the stamp of the outstanding sciontist, in that his experiments woro direct and simple. He knew the questions to ask and how to ask them of the plant itself. His expcrimental work was, however, simple only in its conception. 'The techniques he used were difficult; others who had tried to use them had only partially succecded. They involved the growing of plants in sand culture in which the concontration of the element under examination was reduced beyond the limits of detection by the most sensitive chemical methods. This called for skilled, painstaking and often arduous work. One by ono the difficultics were overcome and the results applied in the field. At no time did Wallace lose sight of the practical objective from which his work had started. Howovor fundamental the investigation might bccome there was always a clear link with the growing plant. Two years after his appointment to the Institute he published tho first of his many papers on plant nutrition. At that time he was concentrating on fruit trees and made his first contribution to the fruit growers by showing that the sorious disease of marginal leaf scorch was due to a deficiency of potash and could be cured by manurial treatment.

When for the second time war brought the need for intensified food production, Wallace extended his work to horticultural and agricultural crops. Ho devised simple field experiments, based on his knowledge of the visual symptoms of micronutricnt deficiencies, to show where tho newly ploughed land was deficient in these clements. Time and again he was ablo to point to the cause of crop failures and to show how they might be overeorne by simple manurial treatments. It became clear that theso visual symptoms, which Wallace and his co-workers could rocognize, should be widely known. This meant colour printing in the middle of the war, but Wallace was determined to accept only pictures which portrayed the conditions accurately. Print after print was oxamined and rejected until at last he was satisficd, and in 1943 his book The Diagnosis of Mineral Deficiencies in Plants by Visual Symptoms: a Colour Atlas and Guide, was published. It is now in its third edition and is acecpted as the standard work on the subject.

The impact of Wallace's work on agriculture and horticulture has becn felt throughout tho world. Evidence of micronutrient deficioncios has been recognized and 